\title{
A History of the Development of Radiofrequency Neurotomy
}

\author{
Marc Russo (1D) ${ }^{1-3}$ \\ Danielle Santarelli (iD ${ }^{2}$ \\ Robert Wright ${ }^{4}$ \\ Chris Gilligan ${ }^{5}$ \\ 'Hunter Pain Specialists, Broadmeadow, \\ NSW, Australia; ${ }^{2}$ Genesis Research \\ Services, Broadmeadow, NSW, Australia; \\ ${ }^{3}$ School of Medicine and Public Health, \\ College of Health, Medicine and \\ Wellbeing, University of Newcastle, \\ Callaghan, NSW, Australia; ${ }^{4}$ Sydney Pain \\ Management Centre, Wahroonga, NSW, \\ Australia; ${ }^{5}$ Brigham \& Women's Hospital, \\ Boston, MA, USA
}

\begin{abstract}
The technique of lumbar medial branch radiofrequency neurotomy for facet joint pain has an intriguing history involving a diverse timeline of medical specialists. This paper aims to chart the pathway that led to its invention and the series of modifications and refinements that have led to modern practice. The story begins with the treatment of World War I soldiers by Nesfield, who used scalpels to cut "trapped" nerves. Inspired by Nesfield's treatment, Rees developed the "percutaneous rhizolysis" technique in 1960. Shealy was the first to use radiofrequency electrodes for denervation of the facet joints, introducing his technique in 1971. Several radiofrequency electrode developments came about from collaborations with Cosman medical device entrepreneurs during the 1970s, including the Shealy Rhizolysis Kit, the Ray Rhizotomy Electrode, and the Sluijter-Mehta Kit. Subsequent dissections of Rees' technique and modification of Shealy's procedure by Bogduk saw the development of "percutaneous lumbar medial branch neurotomy" in 1980 by Bogduk and Long. Bogduk continued to contribute significantly to validation, refinement and acceptance of the technique. In 1998, the technique of pulsed radiofrequency was invented by Sluijter, Cosman, Rittman and van Kleef. Subsequent innovations have consisted of cooled radiofrequency neurotomy, multi-tined cannulae, endoscopic systems, and alternative denervation targets, such as the facet joint capsule. As we pass the first 100 years of the story, we believe there are more chapters to be written on this fascinating subject.
\end{abstract}

Keywords: radiofrequency, neurotomy, low back pain, facet joint, history, medial branch

\section{Introduction}

Radiofrequency neurotomy (RFN) of the lumbar medial branch for facet joint proven low back pain (via validated medial branch block paradigms) is an established treatment that has continued since its invention in the early 1970s. Whilst modern descriptions of the technique and its results abound, ${ }^{1-3}$ there is little collated information on the historical path of invention and refinement of technique that has led to modern practice. This paper aims to chart the circuitous pathway taken and to inform the reader of how inspiration, anecdotal claims, serendipity, and finally scientific rigor has shaped the treatment we know and use today. This paper is not a discursive review of the tenets of the modern technique and the reader is referred to the relevant papers that address that. ${ }^{1-3}$

\section{History}

Prior to 1934, the year in which Mixter and Barr published on the slipped disc, ${ }^{4}$ low back pain was considered some form of inflammatory condition, going under the rubric of lumbago and other descriptors. Treatment was varied, eclectic, and 
essentially unsuccessful. The natural history of the condition played out with various therapies applied.

\section{Vincent Nesfield - Trench Back and Treatment}

Vincent Nesfield was born in India in $1879 .{ }^{5}$ He entered medical school directly from school, joined the Indian Medical Service at the age of 23 years, and obtained his surgical Fellowship in 1905, practicing as a general surgeon with a special interest in eye surgery. ${ }^{6}$ In 1914, he was stationed in Mesopotamia (now Iraq/Kuwait/Syria) and began seeing and attempting to treat cases of "trench back", a condition found in soldiers of the first World War due to either collapse of earth or sandbags onto a person in a trench or in the process of digging a trench. ${ }^{7,8}$ A contemporaneous definition at the time comes from Captain John D. Sandes of the Kitchener India Hospital in Brighton who published in the British Medical Journal in 1915:

The cases almost invariably come from the trenches. They complain of pain and rigidity in the dorsal-lumbar region. Various degrees of disability are represented. Some can get about, others have to be carried on stretchers. Those who can walk do so with a pronounced stoop, and use a stick. Tenderness is generally present. $^{7}$

The cause was unknown but thought to relate to contusion of the muscles and fascia, and thought to be similar to another condition known at that time as "Railway Spine". 9 Nesfield thought the cause was a sensory nerve caught up in a muscle or tendon and, in 1918, he developed a procedure to treat this. ${ }^{8} \mathrm{He}$ used a fine, long, curved ophthalmic scalpel to insert it on either side of the spine and move it back and forth vertically to "cut" this alleged nerve and "cure" patients.

In 1921, he left the Indian Medical Service and commenced practice in London's Harley Street as an Ophthalmic Surgeon. He continued to treat these patients, typically 6 per week, but never published on his technique. He had published on cataracts and the sterilization of water by adding chlorine. ${ }^{10,11}$

In 1932, Nesfield was deregistered following claims that he had invented an injectable "rejuvenating" substance that cured various conditions, which he called "Vitalexin". ${ }^{12}$ According to evidence presented during his hearings, he had actually used a preparation of activated hormone isolated from embryonic tissue known as "Hormacton", which was discovered by a Russian doctor,
Dr Ischlondsky. ${ }^{12,13}$ The medical profession was appalled by his self-promotion, and he was deregistered at the age of 53 years.

He later moved to Ellenden, Sandhurst, in Kent, where he set up a nursing home, surgery, and laboratory, and continued to work there, as well as at his Harley Street practice (as a deregistered doctor). ${ }^{6}$ His medical fellowship was restored to him in 1951 at the age of 72 years. In 1959, at the age of 80 , he treated Horace Hughes, a London journalist suffering with chronic back pain, with his technique. ${ }^{8}$ Word of Hughes' "miraculous" treatment reached Welsh Urological Surgeon, William Skyrme Rees, who met with Nesfield a short time later and became smitten with the technique. ${ }^{8}$ Nesfield died age 92 in 1972.

\section{William Skyrme Rees - Percutaneous Rhizolysis}

William Skyrme Rees was born on 23rd October 1912. ${ }^{14}$ He graduated from Birmingham University, was a surgeon in the Royal Army Medical Corps during World War II, and later a urological surgeon in Wales. Rees first became aware of Nesfield's procedure after hearing about his treatment of journalist Horace Hughes. Intrigued, he made an appointment with Nesfield and watched him operate. ${ }^{8} \mathrm{He}$ was further influenced by a paper published in 1959 by Dr W. Ritchie Russell, "Discussion on the treatment of intractable pain," which focused on peripheral generators in central pain syndromes. ${ }^{15}$ Rees first performed Nesfield's procedure in June 1960 using a von Graefe cataract knife with great success. ${ }^{8}$

Later in 1960, on a National Health Service sponsored trip to the USA to study cross-infection prevention in hospitals, Rees met with Dr Petersen, who had been trained in the technique of ligament sclerosant therapy invented by $\mathrm{Dr}$ George Hackett in 1953, father of prolotherapy. ${ }^{8}$ This consisted of Pro-Lan Therapy $-2.5 \%$ phenol injected into the facet joint ligaments, as it was Dr Hackett who believed that much back pain originated from the facet and sacroiliac joints. ${ }^{16,17}$ Two cases of paraplegia in the USA dissuaded Skyrme Rees from adopting this approach.

He reports in his self-published medical memoir that he “... devised the operation, which [he] termed Multiple Bilateral Percutaneous Rhizolysis". ${ }^{18}$ This included the use of what he termed the Skyrme-Rees Milliammeter, with which he determined "Travel's Points" as the place to perform his incisions. From his detailed description of 
the procedure, it appears unchanged from Nesfield's Treatment. Between 1960 and 1965, he performed his operation approximately once every three weeks on average on patients referred to him. It was Rees' opinion that he was dividing the dorsal ramus of the facet joint, which he believed was the near universal cause of chronic low back pain. ${ }^{18}$

In 1965, Rees was on a panel to review infection control practices in UK hospitals and reported that they were the dirtiest hospitals in the world. ${ }^{8}$ He refused to retract his report and was suspended from duty. Ostracized by the profession, his appointments terminated, and rendered unemployable, he emigrated to Australia at the age of 53 and began a country general practice in Tocumwal (population 800) in the NSW Riverina. ${ }^{8,14} \mathrm{He}$ never again worked as a urological surgeon. He began a specialized practice treating country patients with chronic low back pain. In 3 years, he treated 1000 patients and established additional consultations in Shepparton, Melbourne, and Sydney. ${ }^{8}$

In 1971, two major events happened. First, he published a letter to the editor on "Multiple bilateral subcutaneous rhizolysis of segmental nerves in the treatment of the intervertebral disc syndrome" in the Annals of General Practice, stating cure of 998 patients out of those first 1000 he treated with his procedure. ${ }^{19}$ This caused a great stir amongst both the national and indeed international medical community for its remarkable claims. ${ }^{20}$ Second was a detailed and favorable report written by the then Federal Health Minister, Dr Doug Everingham, who visited him and described in his report that the procedure was producing "a fibromyotomy of the erector spinae muscles". It was subsequently placed on the Schedule Fee list of the health funds at a relatively high amount of \$250 AUD, ${ }^{21}$ a sum equivalent in 2021 to $\$ 2156$ USD.

In 1972, he left his Australian country practice behind and moved to Macquarie Street (the Australian equivalent of the United Kingdom's Harley Street). He was featured in the popular press on numerous occasions and was invited to give lectures on "Percutaneous Rhizolysis" or "Reesolysis", as he would often call it, stating that he alone had invented it. ${ }^{8}$ He lectured at the 12th Congress of the Pan Pacific Surgical Association in Hawaii, ${ }^{22}$ and his work was featured on the Australian Broadcasting Network's Four Corners program, although he was not named. ${ }^{8}$ He presented to the Department of Anatomy at the University of Sydney, where he performed his technique on cadavers. In 1973, he delivered a lecture at the
Prince Henry Hospital in Sydney, detailing his technique. ${ }^{23} \mathrm{He}$ also lectured at the Annual Meeting of the American Neurological Surgeons in St Louis in 1974.

In 1975, Rees published a second paper, "Multiple bilateral percutaneous rhizolysis", in which he stated that his technique had been performed 20,000 times by his pupils since his 1971 publication with similar results. ${ }^{24}$ Rees' technique was subsequently dissected by anatomist Nikolai Bogduk and colleagues. ${ }^{25}$ They found that the facet joint nerve was never divided in Rees' procedure, only the fascia of muscle, and that he was performing a fasciotomy procedure for muscles in spasm, thus relieving the spasm. Rees forthrightly rejected the findings as bogus.

In 1983, Rees reported in the journal Spine that he had performed the procedure 54,000 times "with great success". ${ }^{21}$ The Neuromyotomy Society was established in 1993, comprising a membership of 40 doctors trained by Rees for a short period. ${ }^{8}$ He retired in 1993 at the age of 80 and died at 81 . The technique nearly died out in Australia in 1980 when the schedule fee for it was slashed to virtually nothing after a medical board review by Dr Finlay. A small group of practitioners continued with the technique until recent times (R. Stuckey, personal communication, 15th February 2021).

\section{Norman Shealy - Radiofrequency Denervation of the Facet Joints}

The famous American neurosurgeon, C. Norman Shealy (Figure 1A), inventor of both transcutaneous electrical nerve stimulation and spinal cord stimulation, and surgeon to John F Kennedy, attended the Pan Pacific Surgical Congress in Hawaii in 1972 where he learnt the surgical technique of percutaneous rhizolysis from Skyrme Rees. ${ }^{26}$

Shealy reported his experience using Rees' surgical technique on 29 patients with a $20 \%$ incidence of unacceptable haematoma formation. ${ }^{27}$ Following this result, he replaced the scalpel incisions with radiofrequency thermistor electrodes that were passed through thin-walled spinal needles, and applied his experience with radiofrequency ablation of the gasserian ganglion, describing his technique as "radiofrequency destruction (coagulation) of the articular nerve supply". ${ }^{28,29}$ His original description of the technique, published in 1973 , read:

Under fluoroscopic guidance 14 gauge thin-walled cannulae are guided adjacent to the centers of tender facet joints. A radio-frequency thermister electrode (19 cm long, 1- 

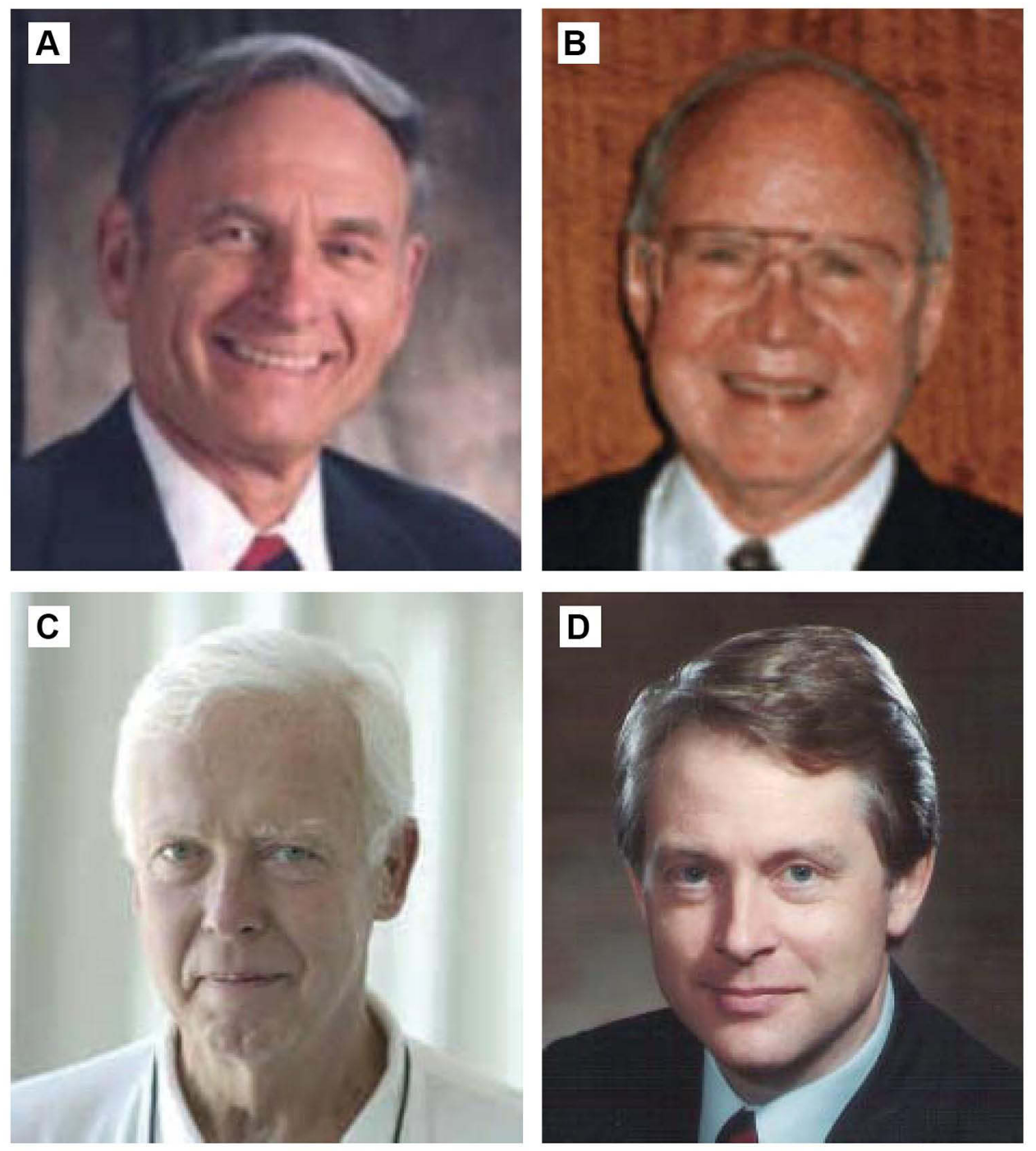

Figure I (A) Dr C. Norman Shealy. (B) Dr Charles Ray. (C) Dr Menno Sluijter. (D) Prof Eric R Cosman Sr.

Notes: Reproduced with permission from Principles and Descriptions of Special Techniques. In: Raj PP and Erdine S (eds). Pain-Relieving Procedures: The Illustrated Guide. John Wiley \& Sons, Ltd.; 2012:68-91. ${ }^{76}$ Copyright @ 2012, John Wiley and Sons.

$2 \mathrm{~mm}$ diameter) is passed through one needle, the needle is withdrawn, and the electrode is slipped over the edge of the facet and advanced to the intertransverse ligament. A lateral x-ray film confirms the position of the electrode and its distance from the main nerve root $\ldots{ }^{28}$

Thus, Shealy was the first to introduce fluoroscopic guidance and invented the technique of percutaneous radiofrequency (RF) denervation of the facet joints. ${ }^{28,29}$

Shealy reported, on a series of 140 patients, a $90 \%$ success rate (defined as "good" or "excellent" response) in virgin back patients with this technique, and a 70\% success rate in patients who had previous lumbar surgery (excluding lumbar fusion, for which a 50\% success rate was reported). ${ }^{28}$ He later published results from a series of
207 patients with longer follow-up intervals, a small portion of which received thoracic and cervical level procedures, reporting a $79 \%$ success rate in previously unoperated patients, and a $41 \%$ success rate in patients with laminectomy (excluding fusion, for which a $27 \%$ success rate was reported). ${ }^{29}$

\section{Nikolai Bogduk - Percutaneous Lumbar Medial Branch Neurotomy}

Nikolai Bogduk (Figure 2) is a prominent figure in the history of the facet joint and RFN. He remains active in the field and continues to publish papers, many of them seminal (now over 280, PubMed accessed 28th January 2021). He has literally had a front row seat to 


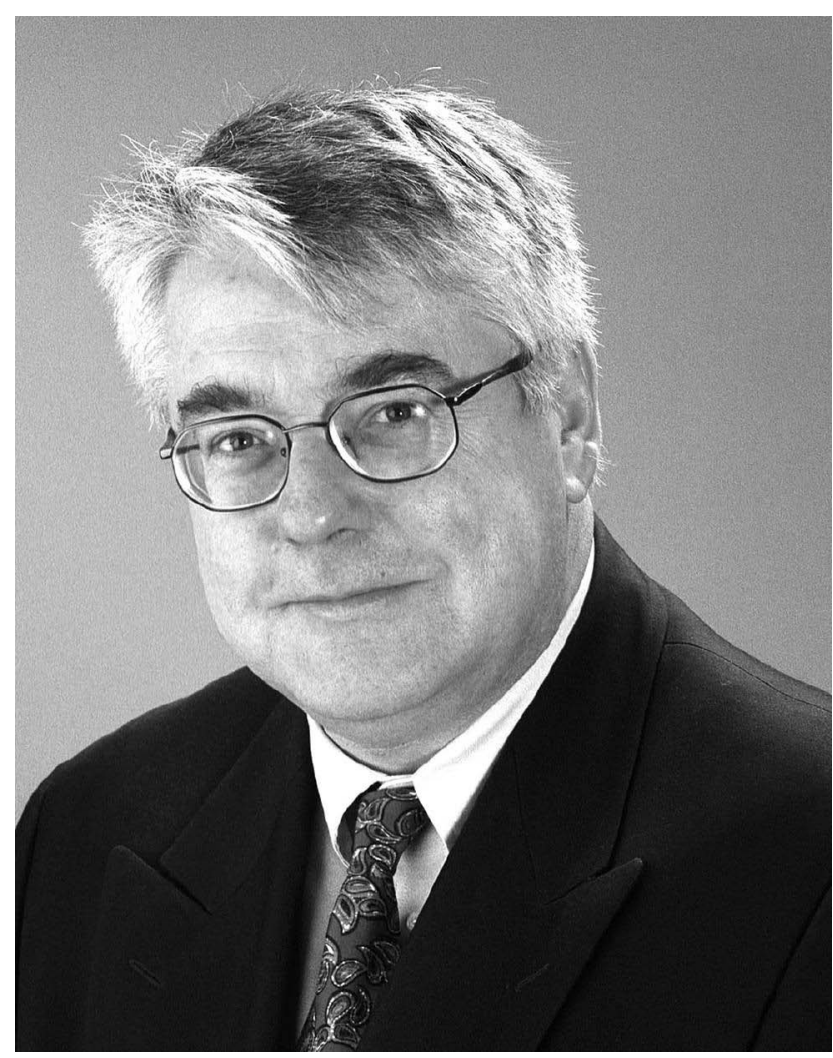

Figure 2 Prof Nikolai Bogduk.

Notes: Reproduced from The Australian Pain Society; 2008 Distinguished Member Awards. Available from: https://www.apsoc.org.au/PDF/Distinguished_Members/ 08 DISTMEMBawards_BOGDUK_N.pdf. Accessed December 6, $2021 .^{40}$ ○ 2008 Australia Pain Society.

the evolution of this therapy and has been responsible for many of the foundational innovations and refinements to the technique.

Bogduk's career began early after medical school in 1972, working as a postgraduate student at Johns Hopkins Hospital in a department of anatomy. He worked with Shealy for a time, being exposed to the early work on spinal cord stimulation and operant conditioning (the forerunner of cognitive behavioural therapy). ${ }^{30}$ His interest in understanding spinal pain led to him working with Professor Lance (a neurologist and doyen of headache research) as a $\mathrm{PhD}$ student at the University of NSW, Australia, during which he continued his anatomy studies and became interested in spinal musculoskeletal medicine. He performed anatomical dissections on the dorsal rami of several mammalian species. $^{31,32}$

Bogduk was later involved in cadaveric dissection of tissue where Skyrme Rees' percutaneous rhizolysis procedure had been performed. He was able to show that the technique did not reach or transect the dorsal rami, thus debunking the claims of Rees. ${ }^{25} \mathrm{He}$ also discovered an anatomical error in Shealy's technique. He found that the technique was not actually targeting the articular nerve supply to the lumbar facet joints, but the medial branch of the dorsal ramus, which he explained in his seminal publication on the anatomy of the human dorsal rami in $1979,{ }^{33}$ and in subsequent publications. ${ }^{34,35}$

Building on the work of Shealy, the technique was subsequently modified by Bogduk and collaborator Don Long and renamed "percutaneous lumbar medial branch neurotomy". 36 This technique was first introduced in 1980 and still remains in use today. In the same year, Bogduk published a review paper on the dorsal ramus syndrome. ${ }^{35}$ Subsequently, in a tissue and egg white model, he demonstrated that the electrode lesion does not extend beyond the tip of the electrode and thus parallel, not perpendicular, placement is to be desired. ${ }^{37}$ This lesson is still to be learnt by some practitioners today.

In the 1990s and beyond, Bogduk has contributed to validation of the technique and the two-block paradigm of medial branch block for definitive diagnosis of facet joint pain. ${ }^{35,38,39}$

Over a 47-year period and counting, Nikolai Bogduk has brought rational scientific assessment to purported claims of anatomy, diagnosis and treatment in this area. He has probably contributed more significantly than any other individual to both validation and acceptance of this branch of medicine in the relief of pain and suffering. His achievements extend far beyond the realm of the lumbar facet joint, the reader is recommended to the Australian Pain Society's Distinguished Member Award for a review. ${ }^{40}$

\section{Radiofrequency Developments Radiofrequency Electrode Series}

In 1971, Shealy worked with Eric R. Cosman Sr (Figure 1D) and Bernard J. Cosman, medical device entrepreneurs for Cosman company Radionics, to produce the SRK - Shealy Rhizolysis Kit. The SRK consisted of a set of $14 \mathrm{G}$ spinal needles and a $16 \mathrm{G}$ RF electrode that was insulated except for a $7 \mathrm{~mm}$ active tip. The electrode could be passed through the needle and advanced so that the tip contacts the medial branch supplying the target facet joint, and a temperature-controlled heat lesion could be produced. $^{41}$ This technique was performed by neurosurgeons under general anaesthesia due to the pain involved in needle placement.

In 1974, a variant of the SRK electrode was developed by American neurosurgeon and clinical engineer 
Dr Charles Ray (Figure 1B) in collaboration with E. R. Cosman Sr. The RRE - Ray Rhizotomy Electrode, produced by Radionics, is a one-piece electrode system for denervation of the facet joints. This electrode has a tissue penetrating tip, a rigid insulated shaft of the needle, and an integrated temperature sensor. ${ }^{41}$ This electrode produced larger lesions and removed the need for spinal needles.

In 1976 or thereabouts, Dutch anaesthesiologist Dr Menno Sluijter (Figure 1C) and E. R. Cosman Sr invented the SMK (Sluijter-Mehta Kit) electrode series in $22 \mathrm{G}, 20 \mathrm{G}$, and $18 \mathrm{G}$ variants. ${ }^{41}$ The technique was similar in that to Shealy's, but with somewhat different target positions and electrode trajectories, and could be used to treat pain of the lumbar and cervical spine due to the finer electrodes. $^{41,42}$ The SMK Kit was transformational as it allowed the procedure to be done under sedation in procedure rooms by anaesthesia-based pain specialists (rather than operating room based neurosurgeons), and allowed for massive increases in the numbers of patients who could be treated and the number of doctors who could be trained in the technique. ${ }^{2}$

From this point on, advances were made in the RF generators, rather than any further needle/probe developments. The small gauge of the RF needles meant small volume lesions were created, and thus more lesions were required to achieve a successful neurotomy. Bogduk and colleagues in the 1990s advocated five or six lesions be made per medial branch supplying the facet joint to be treated, which made it a long procedure to complete. ${ }^{43,44}$

\section{Pulsed Radiofrequency Neurotomy}

The next greatest change to the therapy occurred in 1998, with the introduction of "pulsed radiofrequency" by Sluijter, E. R. Cosman and colleagues. ${ }^{45}$ The invention of this technique came about following a meeting in Austria in 1995 between Sluijter, W Rittman and a Soviet-bloc scientist. The scientist suggested that the pain relief with RF treatment could be due to the strong magnetic fields induced by voltage fluctuations, rather than the destruction of tissue. ${ }^{46}$ Cosman confirmed the historical details in a comment published in Anaesthesiology in $2005 .{ }^{47}$ In his comment, he states that, intrigued by this idea of magnetic field effects, Sluijter and Rittman discussed it with him. He debated that with their RF parameters, any magnetic field effects would be negligible, and that any biological effects not attributable to heating could only possibly be due to the electrical field. Rittman suggested disconnecting the reference electrode in order to remove any electric effects and test only the magnetic field effects, while Cosman argued that any therapeutic effects in such a test could only be due to "either a transient electric field pulse when the radiofrequency is turned on or from capacitively induced radiofrequency electric fields". 47

Sluijter trialled this approach on a small number of patients, however, the success rate was not high enough, thus he suggested that a stream of pulses might produce better pain relief than a transient field pulse. ${ }^{47}$ This led Sluijter, Cosman and Rittman to devise a pulsed RF waveform that would eventually result in the production of the first pulsed RF generator by Radionics. ${ }^{47}$ In early 1996, Sluijter reported promising results with this new device and technique, while Cosman performed extensive calculations to prove that it was the electric fields, not the magnetic fields, providing therapeutic effect.

In their paper published in 1998 in Pain Clinic, ${ }^{45}$ Sluijter, Cosman, Rittman and van Kleef report on 36 patients treated with pulsed RFN of the dorsal root ganglion (temperature limited to 42 degrees, $20-35 \mathrm{~V}, 2$ pulses per second of $20 \mathrm{msec}$ pulse width each). Thirty-one out of the 36 patients perceived significant global benefit. This led to the development of pulsed RFN being applied to major sensory and motor nerves, which heretofore had not been treatable due to the damage caused by a 90-degree temperature lesion.

\section{Cooled Radiofrequency Neurotomy}

Cooled radiofrequency ablation was first developed in the late 1990s for use in the cardiac field for arrhythmia management, ${ }^{48,49}$ and then found application in tumour ablation as a method to enlarge the tumour destruction volume. ${ }^{50-52}$ The technology was first introduced into the pain management field via custom designed equipment for treatment of sacroiliac joint pain. ${ }^{53-58}$ It has since been applied to medial branch neurotomy by McCormick et al in 2014 and validated further. ${ }^{59}$ Although it used a relatively unchanged active tip design, the cooling system allowed for controlled enlarged lesions to be performed without inducing tissue charring. ${ }^{51,52}$ For the definitive engineering analysis of both thermal and cooled RFN, we refer the reader to the opus by Ball. ${ }^{60}$

\section{Tined Needle Designs}

The first of the tined RF cannulae was the Nimbus needle, developed in 2009 by Denver pain specialist Dr Robert Wright (Figure 3A). In 2006, the Canadian based Baylis Medical company asked Wright to evaluate their internally cooled RF electrode for sacroiliac joint RF denervation, and the temperature safety study he performed was 


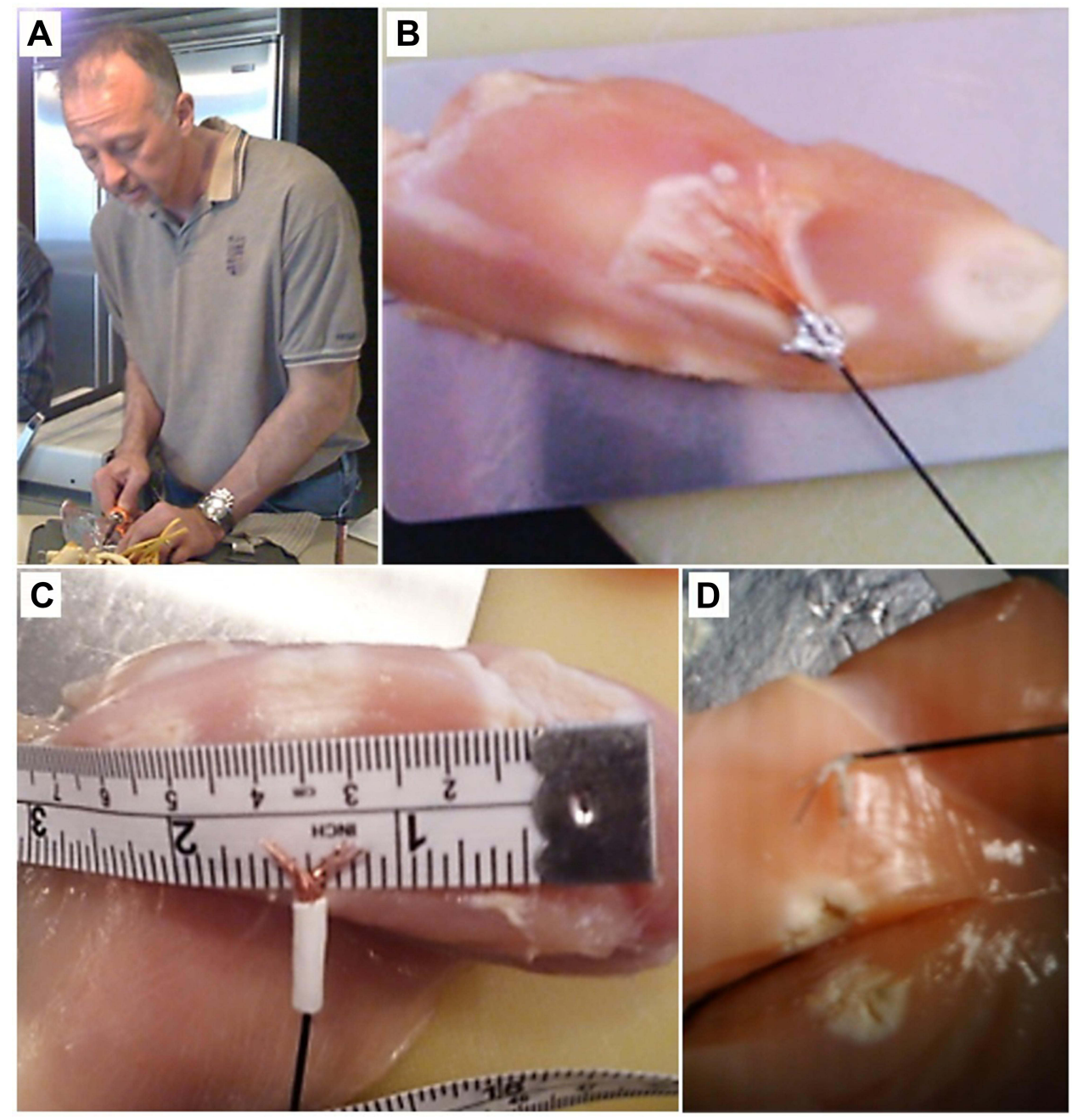

Figure 3 Development of the Nimbus needle. (A) Dr Robert Wright, May 2009 - "day one" of Nimbus invention. (B) Wires soldered onto the tip of a standard 20G cannula. (C and D) Cloud-shaped lesions created by three $27 \mathrm{G}$ spinal needles pushed into a regular cannula (confirmation that the effect was not due to the extreme conductivity of copper).

presented at the 2007 Spine Intervention Society Annual Meeting. ${ }^{61}$ By early 2009, Wright was trying to conceive of an alternative device that could match the lesion created by the internally cooled electrode and be compatible with all RF generators at price that would allow for widespread adoption. In this mindset, he describes nervously fidgeting with his wife's four-prong gem tweezers when he realized that a pronged approach may accomplish what he was looking for. Early "garage" experiments convinced him that a ball-shaped tissue coagulum could be produced and "sculpted" by wires coming off the end of a regular $\mathrm{RF}$ cannula (Figure 3B-D). The lesion created by the crude device was consistently globular or cloud-shaped, hence the name, "Nimbus".

In 2010 , a system to make the tissue lesions in a $37^{\circ} \mathrm{C}$ water bath to account for the known in-vivo heat sink effect, and to thermographically document precise temperature isotherms was developed. ${ }^{62}$ Early on, the exvivo testing showed a lesion topography that would allow for a useful approach to various targets beyond the sacroiliac joint. Specifically, the possibility of targeting the lumbar medial branch from a perpendicular, rather than a more challenging parallel, approach was exciting. Wright also documented a constant lesion size well suited to RF ablation at most spinal targets with a single heat cycle. ${ }^{62}$ Tine exit angle design produced a directional lesion that did not over-extend distally. The first human case was presented at the 2011 European Society of Regional Anesthesia and Pain Therapy (ESRA) meeting in Dresden, Germany. ${ }^{63} \mathrm{CE}$ mark and FDA approval came in 2012. Over the next three years, seminal work on the Nimbus multi-tined expandable electrode came from 
Burnham, Bainbridge, and others addressing procedural time efficiency gains, clinical outcomes, and size of lesion (as demonstrated by MRI scanning). ${ }^{64-67}$

In the following years, a sea change occurred in the RF field around the adoption of the new "large volume lesion" concept $\left(50 \mathrm{~mm}^{3}\right)$ for pain medicine procedures. ${ }^{68}$ Various new multi-tined cannula designs came to market, such as the Venom and Trident cannulae. Further refinements and advancements are expected in the future as the field has seen invigoration and commercial success with technological advances.

\section{Anatomical Developments}

More recent developments have focused on optimizing RF probe placement and targeting alternate structures, such as the facet joint capsule/terminal neural branches. Interesting work has been performed in this area by Yeung et al in 2014, who worked with the Richard Wolf surgical instrument company to develop specialized endoscopic instruments - the Richard Wolf Yeung Endoscopic Spine System (YESS) Rhizotomy Set (Figure 4), commercialized by Elliquence. ${ }^{69}$ The technique is an endoscopic neurectomy of the dorsal ramus. Whilst conceptually appealing, it has not gained widespread adoption in current clinical practice.

Further innovation was produced by Ramirez Leon et al in 2016, who performed a 360-degree facet rhizolysis with a high-frequency RF energy source. ${ }^{70}$ The technique

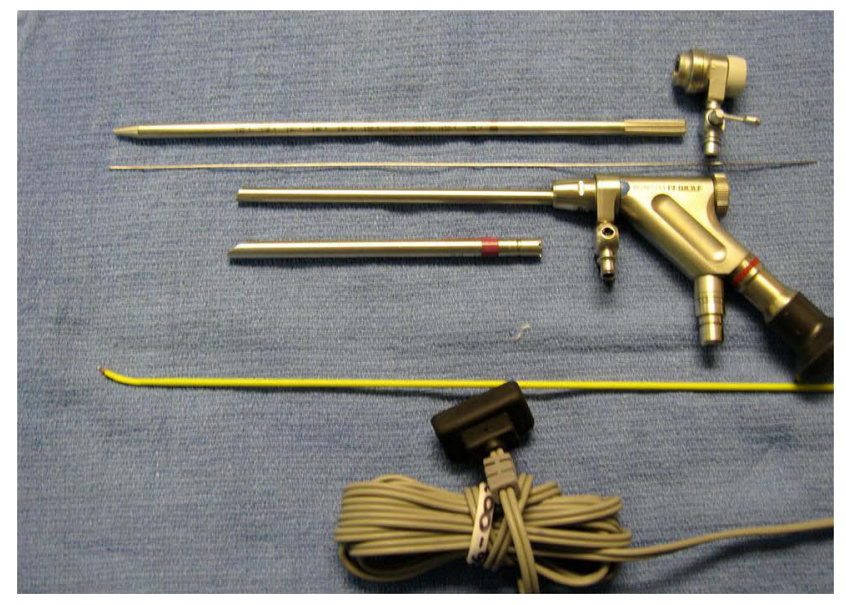

Figure 4 The Richard Wolf Yeung Endoscopic Spine System (YESS) Rhizotomy Set, consisting of cannulae, endoscope, bi-tip probe for tissue cutting, and RF probe for tissue ablation.

Notes: Reproduced from Yeung A, Gore S. Endoscopically guided foraminal and dorsal rhizotomy for chronic axial back pain based on cadaver and endoscopically visualized anatomic study. Int J Spine Surg. 2014;8:23. ${ }^{69}$ Copyright (C) 2014 ISASS International Society for the Advancement of Spine Surgery. Creative Commons Attribution-Noncommercial 3.0 Unported License. involves a 4-lesion radiofrequency cauterization of the edges of the facet joint capsule performed in a circular motion. The facet joint capsule was formerly identified as an alternative denervation target for lumbar facet joint pain by Iwatsuki et al in 2007, who performed laser rhizotomy of the capsule. ${ }^{71}$ Several variations on facet joint capsule denervation have since been published in the literature. $^{72-75}$

\section{Conclusion}

The history of RFN has been a long and winding one. Having started with an eccentric ophthalmologist, followed by an iconoclastic urological surgeon influenced by the inventor of prolotherapy, the story moves to a most remarkable and productive neurosurgeon who teams with a medical device entrepreneur to produce what is recognizable today as the existing therapy. It was validated by an Australian anatomist and then significantly expanded by the enquiring mind of a Dutch anaesthesiologist. Along the way, it has survived the slings of poor practice reports and the arrows of poorly designed trials to remain one of the bedrock foundational techniques of interventional pain medicine. As we pass the first 100 years of the story, we believe there are more chapters to be written on this fascinating subject.

\section{Acknowledgment}

With thanks to Dr Richard Stuckey for additional historical information.

\section{Disclosure}

MR provides unpaid consulting for Abbott, Boston Scientific, Mainstay Medical, Medtronic, Nevro, Presidio Medical, Saluda and Stimwave, conducts sponsored research activities for Boston Scientific, Mainstay Medical, Medtronic, Nevro, Presidio Medical and Saluda, and is a stockholder in Freedom Neuro, Lungpacer, Precise Light Surgical and SPR Therapeutics. RW provides consulting for Abbott and reports patents US10716618B2 and US10736688B2 issued to Stratus Medical, LLC. CG provides consulting for Abbott, Iliad Lifesciences, Medtronic and Saluda, conducts research activities for Mainstay Medical and Sollis Therapeutics, reports personal fees from Medtronic, Abbott, Eli Lilly, Saluda, Persica Pharmaceuticals, Iliad Lifesciences, and Expert Witness, and research support paid directly to their institution by Mainstay Medical, outside the submitted work. MR, RW and CG declare no other potential 
conflicts of interest for this work and declare no consulting, payments received, or other conflicts of interest with any of the companies whose technologies are mentioned in this manuscript. DS has no conflicts of interest for this work to declare.

\section{References}

1. Bogduk N, Dreyfuss P, Govind J. A narrative review of lumbar medial branch neurotomy for the treatment of back pain. Pain Med. 2009;10(6):1035-1045. doi:10.1111/j.1526-4637.2009.00692.x

2. van Eerd M, van Kleef M, Van Zundert J. 62 - Radiofrequency Treatment. In: Benzon HT, Rathmell JP, Wu CL, Turk DC, Argoff CE, Hurley RW, editors. Practical Management of Pain (Fifth Edition). Philadelphia: Mosby; 2014:846-865.e843.

3. Bogduk N. Evidence-informed management of chronic low back pain with facet injections and radiofrequency neurotomy. Spine J. 2008;8 (1):56-64. doi:10.1016/j.spinee.2007.10.010

4. Mixter WJ, Barr JS. Rupture of the Intervertebral Disc with Involvement of the Spinal Canal. $N$ Eng $J$ Med. 1934;211 (5):210-215. doi:10.1056/NEJM193408022110506

5. Nesfield, Vincent Blumhardt (1879-1972). The Royal College of Surgeons of England. Plarr's Lives of the Fellows Web site; 2014. https://livesonline.rcseng.ac.uk/client/en_GB/lives/search/results?qu= \%22RCS:E005981\%22\&rt=false|||IDENTIFIER|||Resource +Identifier. Accessed 19 July, 2020.

6. Robertson TB. Obituary Notices. Br Med J. 1972;1(5800):634-635. doi:10.1136/bmj.1.5800.634.

7. Sandes JD. "Trench Back" Treated by Sodium Salicylate Ionization. Br Med J. 1915;2(2849):215-216. doi:10.1136/bmj.2.2849.215

8. Stuckey R. Say Goodbye to Back Pain. Melbourne: Hill of Content Publishing Company; 1994.

9. Ww G. Railway Spine And Litigation Symptoms. J Am Med Assoc. 1898;XXX(17):956-958. doi:10.1001/jama.1898.72440690016002a

10. Nesfield V. Theories Of Glaucoma And Cataract. Australas J Optom. 1931;14(2):15-17. doi:10.1111/j.1444-0938.1931.tb00039.x

11. Nesfield VB. A chemical method of sterilizing water without affecting its potability. Public Health. 1902;15:601-603. doi:10.1016/ S0033-3506(02)80142-1

12. Harley Street Doctor Struck Off Register. The Mail (Adelaide, SA: 1912-1954) 28 May, 1932.

13. Irvine D. General, Medical Council (Continued). Br Med J. 1932;1 (3726):267-273.

14. Rees, William Skyrme (1912-1994). The Royal College of Surgeons of England. Plarr's Lives of the Fellows Web site; 2016. https:// livesonline.rcseng.ac.uk/client/en_GB/lives/search/results?qu=\% 22RCS:E009189\%22\&rt=false||IDENTIFIER||Resource+Identifier. Accessed 30 July, 2020.

15. Russell WR. Discussion on the treatment of intractable pain. Proc R Soc Med. 1959;52:983-991.

16. Hackett GS. Referred Pain from Low Back Ligament Disability. AMA Arch Surg. 1956;73(5):878-883. doi:10.1001/archsurg.1956. 01280050146026

17. Hackett GS. REFERRED PAIN AND SCIATICA IN DIAGNOSIS OF LOW BACK DISABILITY. $J$ Am Med Assoc. 1957;163 (3):183-185. doi:10.1001/jama.1957.82970380004007b

18. Rees WS. A Dissertation on the Relief of Pain. 1990.

19. Rees WES. Multiple bilateral subcutaneous rhizolysis of segmental nerves in the treatment of the intervertebral disc syndrome. Ann General Practice. 1971;16:126-127.

20. Bogduk N. 'Rhizolysis' and low back pain. Med J Aust. 1977;1 (14):504.

21. Rees S. Letters. Spine. 1983;8(1):118-120. doi:10.1097/00007632198301000-00022
22. Gainor B. The forgotten nerve. J Am Osteopath Assoc. 1978;78 (October):108/144-109/145.

23. Practical Regional Analgesia. Ja L, Bryce-Smith R, editors. Monographs in Anesthesiology. Vol. 5: Excerpta Medica; Amsterdam, Oxford, New York; 1976.

24. Rees WS. Multiple bilateral percutaneous rhizolysis. Med J Aust. 1975;1(17):536-537. doi:10.5694/j.1326-5377.1975.tb111567.x

25. Bogduk N, Colman RR, Winer CE. An anatomical assessment of the "percutaneous rhizolysis" procedure. Med J Aust. 1977;1(12):3 97-399. doi:10.5694/j.1326-5377.1977.tb130762.x

26. Shealy CN. Miracles Do Happen: A Physician's Experience with Alternative Medicine. Element; 1995.

27. Shealy CN, Preito A, Burton C, Lond DM Radiofrequency percutaneous rhizotomy of the articular nerve of Luschka: an alternative approach to chronic low back pain and sciatica. Annual Meeting of the American Association of Neurological Surgeons: Los Angeles; 1973.

28. Shealy CN. Facets in back and sciatic pain. A new approach to a major pain syndrome. Minn Med. 1974;57(3):199-203.

29. Shealy CN. Percutaneous radiofrequency denervation of spinal facets. Treatment for chronic back pain and sciatica. $J$ Neurosurg. 1975;43(4):448-451. doi:10.3171/jns. 1975.43.4.0448

30. Emeritus Professor Nikolai Bogduk/Staff Profile. The University of Newcastle Australia; 2020. https://www.newcastle.edu.au/profile/nikbogduk. Accessed 30 January, 2021.

31. Bogduk N. The lumbosacral dorsal rami of the cat. J Anat. 1976;122 (Pt 3):653-662.

32. Bogduk N. Proceedings: the lumbosacral dorsal rami of the monkey and dog. J Anat. 1974;118(Pt 2):393-394.

33. Bogduk N, Long DM. The anatomy of the so-called "articular nerves" and their relationship to facet denervation in the treatment of low-back pain. J Neurosurg. 1979;51(2):172-177. doi:10.3171/ jns.1979.51.2.0172

34. Bogduk N, Wilson AS, Tynan W. The human lumbar dorsal rami. J Anat. 1982;134(Pt 2):383-397.

35. Bogduk N. Lumbar dorsal ramus syndrome. Med J Aust. 1980;2 (10):537-541. doi:10.5694/j.1326-5377.1980.tb100759.x

36. Bogduk N, Long DM. Percutaneous lumbar medial branch neurotomy: a modification of facet denervation. Spine. 1980;5(2):193-200. doi:10.1097/00007632-198003000-00015

37. Bogduk N, Macintosh J, Marsland A. Technical limitations to the efficacy of radiofrequency neurotomy for spinal pain. Neurosurgery. 1987;20(4):529-535. doi:10.1227/00006123-198704000-00004

38. Schwarzer AC, Derby R, Aprill CN, Fortin J, Kine G, Bogduk N. Pain from the lumbar zygapophysial joints: a test of two models. $J$ Spinal Disord. 1994;7(4):331-336. doi:10.1097/00002517199408000-00007

39. Schwarzer AC, Aprill CN, Derby R, Fortin J, Kine G, Bogduk N. Clinical features of patients with pain stemming from the lumbar zygapophysial joints. Is the lumbar facet syndrome a clinical entity? Spine. 1994;19(10):1132-1137. doi:10.1097/00007632-19940500100006

40. Distinguished Member Awards (Nikolai Bogduk). The Australian Pain Society; 2008.

41. Cosman ER, Cosman ER. Radiofrequency Lesions. In: Lozano AM, Gildenberg PL, Tasker RR, editors. Textbook of Stereotactic and Functional Neurosurgery. Berlin, Heidelberg: Springer Berlin Heidelberg; 2009:1359-1382.

42. Mehta M, Sluijter ME. The treatment of chronic back pain. A preliminary survey of the effect of radiofrequency denervation of the posterior vertebral joints. Anaesthesia. 1979;34(8):768-775. doi:10.1111/j.1365-2044.1979.tb06410.x

43. Lord SM, Barnsley L, Bogduk N. Percutaneous radiofrequency neurotomy in the treatment of cervical zygapophysial joint pain: a caution. Neurosurgery. 1995;36(4):732-739. doi:10.1227/00006123199504000-00014 
44. Lord SM, McDonald GJ, Bogduk N. Percutaneous Radiofrequency Neurotomy of the Cervical Medial Branches: a Validated Treatment for Cervical Zygapophysial Joint Pain. Neurosurg Q. 1998;8 (4):288-308. doi:10.1097/00013414-199812000-00004

45. Sluijter M, Cosman E, Rittman W, Van Kleef M. The effect of pulsed radiofrequency fields applied to the dorsal root ganglion-A preliminary report. The Pain Clinic. 1998;11:109-117.

46. Richebe P, Rathmell JP, Brennan TJ. Immediate early genes after pulsed radiofrequency treatment: neurobiology in need of clinical trials. Anesthesiology. 2005;102(1):1-3. doi:10.1097/00000542200501000-00002

47. Cosman ER. A comment on the history of the pulsed radiofrequency technique for pain therapy. Anesthesiology. 2005;103(6):1313-1314. doi:10.1097/00000542-200512000-00028

48. Calkins H, Epstein A, Packer D, et al. Catheter ablation of ventricular tachycardia in patients with structural heart disease using cooled radiofrequency energy: results of a prospective multicenter study. Cooled RF Multi Center Investigators Group. J Am Coll Cardiol. 2000;35(7):1905-1914. doi:10.1016/S0735-1097(00)00615-X

49. Delacretaz E, Stevenson WG, Winters GL, et al. Ablation of ventricular tachycardia with a saline-cooled radiofrequency catheter: anatomic and histologic characteristics of the lesions in humans. J Cardiovasc Electrophysiol. 1999;10(6):860-865. doi:10.1111/ j.1540-8167.1999.tb00267.x

50. Hacker A, Vallo S, Weiss C, et al. Technical characterization of a new bipolar and multipolar radiofrequency device for minimally invasive treatment of renal tumours. BJU Int. 2006;97(4):822-828. doi:10.1111/j.1464-410X.2006.06038.x

51. Lorentzen T. A cooled needle electrode for radiofrequency tissue ablation: thermodynamic aspects of improved performance compared with conventional needle design. Acad Radiol. 1996;3(7):556-563. doi:10.1016/S1076-6332(96)80219-4

52. Goldberg SN, Gazelle GS, Solbiati L, Rittman WJ, Mueller PR. Radiofrequency tissue ablation: increased lesion diameter with a perfusion electrode. Acad Radiol. 1996;3(8):636-644. doi:10.1016/S1076-6332(96)80188-7

53. Stelzer W, Aiglesberger M, Stelzer D, Stelzer V. Use of cooled radiofrequency lateral branch neurotomy for the treatment of sacroiliac joint-mediated low back pain: a large case series. Pain Med. 2013;14(1):29-35. doi:10.1111/pme.12014

54. Patel N, Gross A, Brown L, Gekht G. A randomized, placebo-controlled study to assess the efficacy of lateral branch neurotomy for chronic sacroiliac joint pain. Pain Med. 2012;13 (3):383-398. doi:10.1111/j.1526-4637.2012.01328.x

55. Malik K, Benzon HT, Walega D. Water-cooled radiofrequency: a neuroablative or a neuromodulatory modality with broader applications? Case Rep Anesthesiol. 2011;2011:263101. doi:10.1155/ 2011/263101

56. Karaman H, Kavak GO, Tufek A, et al. Cooled radiofrequency application for treatment of sacroiliac joint pain. Acta Neurochir. 2011;153(7):1461-1468. doi:10.1007/s00701-011-1003-8

57. Kapural L, Stojanovic M, Sessler DI, Bensitel T, Zovkic P. Cooled radiofrequency (RF) of L5 dorsal ramus for RF denervation of the sacroiliac joint: technical report. Pain Med. 2010;11(1):53-57. doi:10.1111/j.1526-4637.2009.00772.x

58. Kapural L, Nageeb F, Kapural M, Cata JP, Narouze S, Mekhail N. Cooled radiofrequency system for the treatment of chronic pain from sacroiliitis: the first case-series. Pain Pract. 2008;8(5):348-354. doi:10.1111/j.1533-2500.2008.00231.x

59. McCormick ZL, Walker J, Marshall B, McCarthy R, Walega DR, Novel A. Modality for Facet Joint Denervation: cooled Radiofrequency Ablation for Lumbar Facet Syndrome. A Case Series. Phys Med Rehabil Int. 2014;1(5):5.
60. Ball RD. The science of conventional and water-cooled monopolar lumbar radiofrequency rhizotomy: an electrical engineering point of view. Pain Physician. 2014;17(2):E175-211. doi:10.36076/ppj.2014/ 17/E175

61. Wright R, Wolfson J, DiMuro J, Peragine J, Bainbridge S In vivo temperature measurement during neurotomy for sacroiliac joint pain using the Baylis SInergy Probe. Paper presented at: Proceedings of the ISIS 15th Annual Meeting; 2007.

62. Wright RE, Brandt SA an ex vivo study on radiofrequency tissue ablation using a novel multitined expandable electrode. International Spine Invervention Society: 19th Annual Scientific Meeting; 2011.

63. Wright RE, Brandt SA Lumbar Medial Branch Neurotomy Using a Novel Multitined Expandable Electrode, Case Report with EMG of the Segmental Multifidus at One Month. European Society of Regional Anaesthesia (ESRA): 30th Annual Congress; 2011.

64. Wright R, Allan K, Kraft M, Holley B. Radiofrequency Ablation Using a Novel Multitined Expandable electrode: device Description and Research Study. Minimally Invasive Surgery for Pain. 2012;2:41-54.

65. Bainbridge JS, Wright RE, Pappas CD, Light S, McQueen RB Technical Efficacy of a Direction Specific Radiofrequency Device in the Performance of Lumbar Medial Branch Neurotomies - an MRI and EMG Confirmation Study (Interim Analysis). International Spine Intervention Society: 23rd Annual Scientific Meeting; 2015.

66. Burnham R Comparison of Lumbar Facet Radiofrequency Neurotomy Using a Conventional Monopolar versus Multitined Electrode. International Spine Intervention Society: 23rd Annual Scientific Meeting; 2015.

67. Wright RE, Allan KJ, Bainbridge JS In and Ex Vivo Validation of a Novel Technique for Radiofrequency Denervation of the Dorsal Sacroiliac Joint Including a Case Study. European Society of Regional Anaesthesia \& Pain Therapy (ESRA): 32nd Annual Congress; 2013.

68. Cosman ER Jr, Dolensky JR, Hoffman RA. Factors that affect radiofrequency heat lesion size. Pain Med. 2014;15(12):2020-2036. doi:10.1111/pme. 12566

69. Yeung A, Gore S. Endoscopically guided foraminal and dorsal rhizotomy for chronic axial back pain based on cadaver and endoscopically visualized anatomic study. Int J Spine Surg. 2014;1;8.

70. Leon JF, Ortiz JG, Fonseca EO, Martinez CR, Cuellar GO. Radiofrequency Neurolysis for Lumbar Pain Using a Variation of the Original Technique. Pain Physician. 2016;19(3):155-161. doi:10.36076/ppj/2019.19.155

71. Iwatsuki K, Yoshimine T, Awazu K. Alternative denervation using laser irradiation in lumbar facet syndrome. Lasers Surg Med. 2007;39 (3):225-229. doi:10.1002/lsm.20459

72. Russo Ma, Santarelli DM. Development and Description of a New Multifidus-Sparing Radiofrequency Neurotomy Technique for Facet Joint Pain. Pain Pract. 2021;21(7):747-758. doi:10.1111/papr.13010

73. Palea O, Andar HM, Lugo R, Granville M, Jacobson RE. Direct Posterior Bipolar Cervical Facet Radiofrequency Rhizotomy: a Simpler and Safer Approach to Denervate the Facet Capsule. Cureus. 2018;10(3):e2322. doi:10.7759/cureus.2322

74. Moussa WM, Khedr W. Percutaneous radiofrequency facet capsule denervation as an alternative target in lumbar facet syndrome. Clin Neurol Neurosurg. 2016;150:96-104. doi:10.1016/j.clineuro.2016.09.004

75. Jacobson RE, Palea O, Granville M. Bipolar Radiofrequency Facet Ablation of the Lumbar Facet Capsule: an Adjunct to Conventional Radiofrequency Ablation for Pain Management. Cureus. 2017;9(9): e1635. doi:10.7759/cureus.1635

76. Principles and Descriptions of Special Techniques. Raj PP, Erdine Seditors. Pain-Relieving Procedures: The Illustrated Guide. 68-91. John Wiley \& Sons, Ltd; 2012. 


\section{Publish your work in this journal}

The Journal of Pain Research is an international, peer reviewed, open access, online journal that welcomes laboratory and clinical findings in the fields of pain research and the prevention and management of pain Original research, reviews, symposium reports, hypothesis formation and commentaries are all considered for publication. The manuscript management system is completely online and includes a very quick and fair peer-review system, which is all easy to use. Visit http:// www.dovepress.com/testimonials.php to read real quotes from published authors. 